\title{
Navigating in the Landscape of Care: A Critical Reflection on Theory and Practise of Care and Ethics
}

\author{
Eva Skærbæk
}

Published online: 30 October 2010

(C) The Author(s) 2010. This article is published with open access at Springerlink.com

\begin{abstract}
The theory and practise of care is defined and enacted differently in different national as well as cultural contexts, illuminating how differently constructed the personal and societal structures in Europe are. A common trait is however that care work paid or non-paid, private or public is identified with women. To navigate in the landscape of care and ethics requires taking into account the constitutive relation between one's identity, embodiment and position. The author suggests conceiving care as an existential condition of life demanded from all human beings. This will free care from the identification with women and pave a way towards a more gender equal and just society with less gender segregation in the labour market and at the arena of education.
\end{abstract}

Keywords Ethics $\cdot$ Care $\cdot$ Gender $\cdot$ Identity $\cdot$ Power

\section{Introduction}

In Norway we find the most gender segregated labour market in Europe and a vast market of part time jobs mostly occupied by women. According to Esping-Andersen [6] it has been possible to combine high female participation with high birth rates only at the cost of extraordinarily gender segregated employment. The majority of contemporary Scandinavian women opt for the dual-role model, intent on lifetime employment, but unwilling to sacrifice motherhood. In Scandinavia the rising birth rates are closely related to public expansion of welfare, health, and education services.

Is it on this background, Esping-Andersen asks, possible to conceive a society with a labour market that optimises not only women's ability to work and have

E. Skærbæk (ه)

Østfold University College, 1757 Halden, Norway

e-mail: eva.skarbak@hiof.no 
children, but one that also lessens gender segregation? His conclusion is that the key issue of gender equality (like any inequality) lies in life course dynamics; true gender equality will not come about unless, somehow, men can be made to enter a more feminine life course. To some degree men in Scandinavia are doing this; increasingly they take parent leave, contribute more at home, and they often refuse to travel in business. This has however so far had little influence on the gender segregation in the labour market and at the arena of education. There are still a majority of women in health and social studies, and a majority of men in engineering, and IT; a difference that is connected with value and recognition.

Teaching, supervising and doing research within the arena of health and social work has taught me how difficult it is for female professionals to get recognition for their work, often also by themselves. This holds at a personal level as well as at an institutional level. For four years I was elected member of the board of the University College at which I work. Soon I became aware of how my department of Health and Social Studies is the least recognised of all departments. The staff at this department is working more hours and having less time to do research than their colleagues at the more male staffed departments such as engineering, teaching, and IT. In my view this is owed to the fact that the majority of the workforce in my department is female, and that the areas of care and social work are perpetually linked to women. Both ingredients are working together, reproducing a disadvantage that is difficult to change. The leaders of my department realise that they are acting as good girls, following all the rules and expectations. Thus, in spite of a constant frustration, every one of us contributes to the cementation of this societal and academic hierarchy. As I write this article, nurses in Norway are pictured with a beard demonstrating that the inequality in wage paid for the same level of competence is gender biased. Maybe these bad girls of the next generation represent a hope for the change that good girls shall never experience.

Inspired by various ethical theories and own empirical research I suggest placing care in a broader phenomenological understanding. Like Tronto [18], I maintain that there is no starting point for care; it is part of life itself and thus part of the responsibility of every human being whichever culture, gender, position, and age. In the following I will shortly resume the history of care ethics and present some challenges of today. Secondly I will look into some ethical approaches addressing care as part of the basic ontology of human existence. Together with my own empirical studies revealing how power and gender conflate our relations and interactions privately and publicly from birth to death, I shall argue that care is a necessary condition of life. Care is an ontological given in the sense that to live is to care in the framework of interdependency [17]. When care is defined as an existential condition of life, demanded from all of us, it opens up for a more gender equal and just society with lesser gender segregation in the labour market and at the arena of education.

\section{Ethics of Ontological Interdependency}

Since Gilligan [7] the scholarship on care and care ethics has exploded. In Ethics of Care and Feminist Ethics [2] Diemut Bubeck renders a thorough review of the 
publications, discussions, problems and perspectives of care in the last 15 years. In spite of many differences the commonality between them is that care so far has taken place under oppressive conditions. The major problem with care and care ethics is what they signify and symbolise. Care is probably the most significant and important category of work that is accorded to women via the sexual division of labour, and a lot of it continues to be done unpaid or badly paid-if the latter, then often by women from less privileged class and ethnic backgrounds.

Care is thus inextricably intertwined with oppressive gender divisions: care is done by women, it is associated with women and it expresses and symbolises femininity [2, p. 26].

According to Bubeck the enthusiasm for theorising care neglects the extent to which theory is corrupted by the oppressive conditions under which care is practised. As a result the only themes of distortion discussed by care ethicists are self-sacrifice and self-denial. On this background Diemut Bubeck suggests theories of care to take into account that practise of care reflects the conditions under which it takes place, otherwise it will paint a distorted picture of care. It is necessary to look into questions such as: the boundaries between carer and cared- for example the danger of solving the problems for the one in need of care rather than letting him/her find a solution in their own time and on their own condition. Closely linked to this is the conflict of need between carer and cared-for; the problem of the care person seeing the other person's needs when they are in conflict with his or her own. Together these questions amount to the more general question of use and misuse of power in the best intention. More recently some authors have addressed these questions, however mostly within the frame of celebrating care and care ethics, while others, like Joan Tronto and Selma Sevenhuijsen have been concerned about the less fortunate conditions under which care often is practised which again influences recognition and payment. In this article, however, I shall focus on some ethical approaches placing the questions raised by Bubeck in an ontological and phenomenological context, universal and relevant for all human beings.

Løgstrup [13] is well known in Denmark and Norway and lately his philosophy has caught increasing interest abroad. The title "Infinitely Demanding" reveals just how inspired Simon Critchley [4] is by Løgstrups philosophy of the ethical demand. Drawing on Husserl, Heidegger, Lipps, a.o. Løgstrup points to the ethical significance of phenomenology and has been presented as giving a key critique of modern rationality [20]. Being a Danish citizen I studied theology, including the subject of ethics, at Århus University where Løgstrup was a professor gathering listeners from within and outside the academia until his death in 1981.

The ethical theory of Løgstrup is linked mostly to his early philosophy, especially his book The Ethical Demand, published in 1958; in English 1972, 1989. Here it reads that the basic ontology of human existence is interdependency. The ethical demand springs from this interdependency requiring each human to take care for the Other without taking responsibility from him or her. Whether this Other is capable of formulating her want or not, the challenge of the ethical demand is that it requires that I-i.e. any one of us - use our knowledge, understanding and love to consider what is in the Other's best interest. 
It is necessary to underline that Løgstrup does not address the question of care. If Løgstrup had addressed it, he would have been concerned about the powerlessness of the patient and the power of the institutional system [8, 11]. And most probably Løgstrup would have consented to Bubeck arguing that there are no pockets of nondistorted caring and that selfloss is a risk, not only in the practise of care but as an existential danger to everyone living in a relation. The concept, even the word care, may not cover the intention of Løgstrup. His perception however, makes a difference in the understanding of care. While traditionally care is recognised as something you can do or not do, care in the framework of interdependency is a necessary condition of life. Within the framework of interdependency we, men and women, as human beings, are dependent and independent throughout life. This differs radically from the tradition that has taught us to develop from dependency into independent and autonomous adults.

By taking ontological interdependency as a point of departure the question is no longer whether to interfere or not. Interdependency means that every one of us holds some of the life of the other in our hand. Continuously confronted with each other's lives it is not possible not to be involved, to use another word than care. If I choose to do nothing, also my not doing or not saying will make a difference. We are interdependent in the sense that we influence each other with what we do and say and by what we do not say and do; we are each other's authors, to use a metaphor of Max Frisch.

The danger of transgressing boundaries is always there, because the ethical demand is including all of us always. In the relation between any two persons there is a tension between dependence and independence: between the other being totally in my hand and the other being responsible for herself and vice versa. This is maybe the most common ethical dilemma of everyday life, well known to all of us. What is in the best interest of the other person whether she is my child, spouse, client, or colleague? According to Løgstrup it does not suffice to do what the other person tells me to do. This only tells that I am not really concerned about the other. Although I am not supposed to take responsibility away from the other person, I am supposed to take the ethical demand seriously. And I therefore may have to oppose her verbal or non-verbal wishes if I find it to be in her best interest in the long run. This way Løgstrup maintains the interdependence from which the ethical demand springs while at the same time emphasizing the responsibility of each human person for him or her self and for the other.

That the ethical demand in Løgstrup's philosophy is unilateral and radical, underlining the responsibility of each person has been criticized. It is possible to read Løgstrup as supporting the subject/object system [9] in the sense that the other is an object left to my subjective evaluation of what is best for her. And it is possible to maintain that ethics for Løgstrup fundamentally is about thinking in first persons terms [11]. As pointed out by Søren Holm this leaves the health care areas with the challenge of establishing stable and predictable actions. A health care ethics suitable for modern health care need not only answer Løgstrup's questions of how should $I$ act, but also to the question of how should we act [11]. These critiques are interrelated and well argued. The balance between $I$ and we is relevant; it is however, exactly what Løgstrup's approach inherently criticizes. In my view, the 
critics neglect that radicalism of the demand has to be seen in the framework of interdependency. Each of us is both subject and object, independent and dependent, throughout life. In other words, by turning the question of paternalism versus nonintervention into an ongoing responsibility of both parts, Løgstrup in fact demolishes the subject-object system, consistently concerned about deconstructing the myth of the independent autonomous human being [3, 4]. Ethics is the responsibility of $I$; the demand is personal. As soon as it turns into rules, how we should act, as relevant as it may be at a ward or a hospital, it is necessary to be en garde and observant.

The ethical approach of Løgstrup, his claim of interdependence, offers a productive framework in that it is open to different ways of responding to the 'ethical demand' of the Other. Interdependence means that every one of us are I,s as well as Others. Not one approach to such requests is ethical or unethical per se, which is to say that it is possible to care in many ways.

\section{Empirical Research}

In my study of five social pedagogues in their first year of work they kept returning to the concept of "nearness"; one of them even described that the only way she managed to work was by being "near". When I asked them to define "nearness", and why they found it important, they unanimously said that nearness was necessary to establish a good relation. When I probed what they meant by a good relation, one of them suddenly, and evidently shaken, burst out: "because then the client does what I want her to do!" These informants had, since the last year of their bachelor study, been deeply concerned about how to transfer ethical theories into practise. It was shocking for them to realise how they came to exert the professional power they so determined to avoid. By way of nearness and a good relation they made the client do what they found best. How come that these otherwise fairly professional informants did not see their misuse of power in the best intention?

I was supervisor for a male student in his period of practise at a nursing institution for old people. He is the only male in the nursing staff. He was asked to attend to a resident, also male, who was paralyzed. After some weeks of his practise, the student asked me if he was allowed to focus his report on the difference between men and women. Encouraged by me the student presented a report on a very successful practise, concluding that it is important to get more men into the caring profession! While the conclusion is trivial, his report is brilliant in documenting and analysing how his work came to be such a success. It appeared that the old man was an incarnated patriarch, resisting aggressively help from any of the female staff. The student could well understand why the old man's wife only came visiting now and then. The student was a mature man around 40; adding what he had learnt at school to his own life experience he managed both to encourage the old man and to train him to become much better in managing his handicap. Acknowledging that he had done good professional work, the student insisted that he would never have had a chance if he had not been gendered male. 
When the student added that the only solution was to employ more men, I thought at first that he just made it easy for himself. It took a while before I realised the implications of his report. From the perspective of the student his colleagues were very professional in their way of working; due to their gender, however, they rarely got a chance to prove their competence as a professional one. While his work was seen and recognised as professional work, their work was reduced to care, as something that any one can do.

Without being able to theorise his experience the male student demonstrated how care and ethics in practise is constitutive with gender. It is, however, as he indicated, not gender per se that is the problem. It is the power, the factual and the symbolic power that is allocated to gender that is problematic, not least within the arenas of health and social work. The only way out is to employ more men!

How come that the interdependency works out differently for the sexes? In order to understand what is at stake in the relation of interdependency in general and in the asymmetrical relations of professional care I had to look out for other ethical approaches than Løgstrup's. Although Løgstrup had a phenomenological understanding of the body, seeing the body as something we are and not something we have, he did not address the question of the difference that the sexual embodiment makes.

\section{Ethics of Gendered Interdependency}

Merleau-Ponty in his work on the phenomenology of perception [14], also like Løgstrup neglected the implications of sexual embodiments. He did, however, inspire Simone de Beauvoir who in a review of his book declared that his philosophy has made a new ethics possible by way of abolishing the opposition between subject and object and claiming that the human being is a body. In the nineteenforties and onwards, when Løgstrup was developing his philosophy of the ethical demand, Simone de Beauvoir was developing her ethics of ambiguity. Like Løgstrup, Beauvoir based her ethical understanding on the existential condition of interdependency as common to all of us. While unfolding her ethical understanding, Beauvoir [1] reluctantly had to realise that her intention of replacing the asymmetrical subject/object relation with a relation of symmetry, with intersubjectivity, had to begin with the question: what is a woman, what is the meaning of the being a woman when she is not seen nor sees her self as a subject? [10, 15]. Beauvoir's main point is that woman's specific ethos, no less than a man's, is constituted in a social context as well as in relation to others.

Like Løgstrup, Beauvoir was not concerned about care. In fact I have often wondered what position she would have taken if she had considered that the main occupation of women then as well as today, is to care, due to a gender segregated society. In developing Beauvoir's ethical understanding Diprose [5] shows how it inherently presents a challenge to how ethics of care has developed since Gilligan. Recognising that ethics of care has put the self-other relation on the ethical map Diprose criticizes it for assuming that the self-other relation is already in place, and that the identity and difference of the parts involved is given, prior to care. When 
identity and difference are given, the central theme in an ethics of care is how the other's difference can be considered in one's resolution of moral dilemmas. This withholds the power balance leaving no room for change. In short, the focus on how to understand the difference of the other leads to a celebration of women's relatedness and women's apparently shared moral perspective, keeping women in their place. Instead Diprose suggests giving attention to the implication of two important claims: (a) that the self develops an embodied and sexed identity within and as an effect of a specific social context, and (b) that one's identity is constituted in the context of and through relations with others.

My studies [15, 16] confirm Diprose's theory in how the work of my informants not only is influenced by, but also is inseparable from their bodies and their sexed identity. Their identities - as well as the identity of the client- are fixed and not fixed at the same time, depending on relation and situation, action and interaction. At the level of practise as well as at the level of knowledge production and politics, gender identity, or preferably sexual difference, is part of an ongoing negotiation and definition.

There are many examples of how dangerous nearness is for women; most often it implies a female monopolisation of responsibility, damaging for both parts in the professional caring interaction, leaving them with only little recognition and demolishing their professionalism. At the same time nearness is necessary in order to take the ethical demand from each human being seriously. Also the male student had to come close enough to find how to help the old resident in the best possible way. Unlike the female informants he does not use the word "nearness" as he is never conceived as being too near. While most men do not see, or are not raised and trained to see, themselves as gender, most women feel or become aware of their difference, striving to find a way of working that will be acknowledged professionally. Often this results in an ambiguity: partly working the way the culture demands, partly working in her own way (nearness), the female professional often works without getting recognition, not even from her own self. Unable to relate or implement her practise to the theory she was taught at school, she does not see her practise as creating professional knowledge. Consequently she enters a vicious circle of silence, of not contributing to knowledge production [15, p. 204]. In a sad way the male student came to confirm my analysis, that care work is reflecting how power is socially constructed within the societal structures and systems in our society.

Doing studies in various fields of health care made me understand the limitation of Løgstrup's ethical demand. The importance of Løgstrup's gender neutral approach however still exists. It is as important to identify gender and how it is conflated with power, as important it is underline that gender is not to be used as an excuse.

\section{Navigating in the Landscape of Care and Ethics}

Not one ethical approach can cover the complexity of the challenging dilemmas of health and social arenas. It is, however, necessary that ethical theory and practise takes into account that all of us are embodied and gendered human beings, 
dependent and independent, constructing and being constructed by various factors in our personal and public lives. Thereby reflecting the argumentation of Walker [19] that differently placed people have different knowledges, which again presupposes being able to see and reflect critically on one's own cultured social, moral and gendered construction. Only such an ethics will be able to criticise traditional normative ethics, for having failed to implicate the social context for the constitution of identity, and thus for how we respond to the most challenging processes in our society today.

The most challenging processes today are according to Andersen [21] the processes of othering and eldering. These processes begin when each of us enters the need of help. Othering and eldering are two different processes. Othering is the process that makes us the Other, the different one, the one we strongly dislike to be, the one who costs too much. While eldering is something that happens to everyone, othering is something we do to someone. Othering is a psychological and a political process in which we create the Other with perceptions and attitudes, a process that is not restricted to old people in need of help. By not mentioning that othering and eldering are processes conflated with gendered power relations, Andersen comes to underline (with Løgstrup) that the ethical demand is posed to every one of us. At the same time it is important to see and identify how all our relations are inextricably gendered for good and for worse (Beauvoir, Diprose).

This is most convincingly described by Clint Eastwood in his movie Gran Torino. The main character Walt Kowalski, played by Clint Eastwood, is a conservative grumpy old white man who after the death of his wife finds himself estranged by the people surrounding him, different as they all are in colour, culture and religion. He neither likes them nor their children, and this goes for his own children as well. In many ways Kowalski portraits the elderly man, mentioned in my story above. Walt Kowalski is not hit by a stroke, but of an attempt to steal his car, the Gran Torino. A menacing gang has forced the boy in the house next to Kowalski's to do this as an initiation. His sister intercedes for her brother and Kowalski reluctantly accepts that the brother makes amends by working in the service of Kowalski. With this event the movie explodes into an example of how intersubjectivity and interdependency works out in daily life. Both have 'inter' as prefix, indicating a space between the subjects. In this space power is at stake. Exposed to othering and eldering, and exposing others to the same, Walt Kowalski experiences that the self only exists in the complex web of its varied relations, and that it is possible to change by means of accepting the responsibility each of us has as human beings independent of sex, religion, age and culture.

\section{Concluding Remarks}

Gender identity is part of an ongoing negotiation and definition at the level of practise as well as at the level of knowledge production and politics. To pave a way towards a less gender segregated society in the arena of the labour market and in the arena of education I suggest to conceive care as the existential condition of life, thus freeing care from the identification with women. Within the framework of 
interdependency both men and women are, as human beings, dependent and independent throughout life. This differs radically from the tradition that has taught us to develop from dependent into independent and autonomous adults, which again makes a difference in the understanding of care. In this tradition care is understood as something you can do or not do. To argue care as a necessary condition of life is a perspective solidly unfolded in the above mentioned ethical approaches, each in their way describing how every human being from the very beginning of life is inserted as subject, as a citizen, with a need to care and to be cared for.

When care is defined as an existential condition of life, it opens up for various ways of answering the "ethical demand" of the Other. From childhood to old age we live our private lives in a continuous challenge to balance difference and sameness, independence and dependence. One of the most challenging dilemmas of professional life is the same: to live this balance in relations and interactions like the ones between staff and clients, teachers and students. Narratives like Gran Torino remind us that there is only one real citizen, a citizen who locates her/himself within the bonds of human interdependence [12]. To neglect this we come to reduce -as Walt Kowalski does in the beginning of the movie - the world to objects, left to our analysis, and forget how differentiated the world, the language and the bodies in it are. To navigate in the landscape of care requires observing and analysing critically how deeply our personal and societal structures are influenced with ethics, power and gender.

Open Access This article is distributed under the terms of the Creative Commons Attribution Noncommercial License which permits any noncommercial use, distribution, and reproduction in any medium, provided the original author(s) and source are credited.

\section{References}

1. de Beauvoir, S. (1976). The ethics of ambiguity. New York: Carol.

2. Bubeck, D. (1998). Ethics of care and feminist ethics. A review essay. In Women's philosophy review (pp. 22-50).

3. Bugge, D. (2009). Løgstrup og Litteraturen. Klim: Århus.

4. Critchley, S. (2007). Infinitely demanding. Ethics of commitment, politics of resistance. London, New York: Verso.

5. Diprose, R. (1994). The bodies of women, ethics, embodiment and sexual difference. Routledge: London.

6. Esping-Andersen, G. (2002). A new gender contract. In Why we need a new welfare state. Oxford.

7. Gilligan, C. (1982). In a different voice: Psychological theory and women's development. Cambridge, MA: Harvard University Press.

8. Gunder Hansen, N. (1998). En afgrund af tillid. Guide til Løgstrups Univers. København: Gyldendal.

9. Hauge, H. (1992). K.E.Løgstrup: En moderne profet. København: Spektrum.

10. Heinämaa, S. (1997). What is a woman? Hypatia, 12(1), 114-132.

11. Holm, S. (2001). The phenomenological ethics of K.E. Løgstrup — a resurce for health care ethics and philosophy? Nursing Philosophy, 2(1), 26-33.

12. Lister, E. (2003). Citizenship: Feminist perspectives. New York: University Press.

13. Løgstrup, K. E. (1971). The ethical demand. Fortress Press: Philadelphia.

14. Merleau-Ponty, M. (1994). Kroppens fanomenologi. Danmark: Det lille forlag.

15. Skærbæk, E. (2001). WHO CARES, ethical interaction and sexual difference. Unipub 2001, Oslo.

16. Skærbæk, E. (2003). Anerkendelse, frihed og faglighed. En forskningsrapport. Høgskolen i Østfold, 2003, 2005. 
17. Skærbæk, E. (2006). Concepts on the road, travelling, embodied and minotarian: Citizenship, intersubjectivity and responsibility. In Common passion, different voices: Reflections on citizenship and intersubjectivity. Raw nerve Books, University of York.

18. Tronto, J. (2009). Thinking about the nature of partiality and justice in a democratic society. Paper at the workshop: Care and normativity-philosophical and empirical challenges. University of Oslo 27 May 2009.

19. Walker, M. U. (1998). Moral understandings: A feminist study in ethics. Routhledge: New York.

20. Wyller, T. (2010). Ethics and phenomenology in the context of professional practices and theory. In Perceiving the other. Vandenhoeck \& Ruprecht.

\section{Other References}

21. Andersen, P. T. (2009). Aldring og andring.

22. Aftenposten 25. April 2009. 